\title{
PRZESZŁOŚCI FRAGMENTARYCZNE, CZYLI... JAK POWRACAJĄ MINIONE KRAJOBRAZY? WYBRANE PRZYKLADY Z POPULARYZACJI ARCHEOLOGII
}

\author{
Mgr Anna Majewska - Uniwersytet Łódzki \\ Adres korespondencyjny: \\ Wydział Nauk Geograficznych \\ Katedra Geografii Politycznej, Historycznej i Studiów Regionalnych \\ ul. Kopcińskiego 31, 90-142 Łódź \\ e-mail: anna.majewska@op.pl
}

ZARYS TREŚCI: W opracowaniu poddano rozważaniu problematykę, posiadających reprezentacje przestrzennie, formy popularyzowania archeologii i jej dorobku. Na wybranych przykładach dokonano krytycznego omówienia dominujących narracji w popularyzacji archeologii, ze szczególnym uwzględnieniem ich aspektu krajobrazowego, za sprawą włączenia do analizy perspektywy geograficznej (geografii historycznej). Wyróżniono podział na stałe i efemeryczne przestrzenie zachowanych reliktowo i/lub konstruowanych krajobrazów dziedzictwa (heritagescape).

SŁOWA KLUCZOWE: Geografia historyczna, archeologia współczesności, krajobraz dziedzictwa, turystyka historyczna, skansen, odtwórstwo historyczne.

\section{FRAGMENTED PASTS... HOW DO THE HISTORICAL LANDSCAPES RETURN? SELECTED EXAMPLES FROM THE POPULARIZATION OF ARCHEOLOGY}

ABSTRACT: In this analysis, forms of archaeology popularisation with a spatial representation and its output, have been evaluated. On the basis of chosen examples, critical analysis of dominating forms of narration in the archaeology popularisation discourse, especially taking into consideration their landscape aspect (historical geography), has been performed. Permanent and ephemeral relic-preserved spaces and/or heritagescape, have been specified.

KEYWORDS: Historical geography, archaeology of the contemporary past, heritagescape, cultural tourism, open-airmuseum, historical reenactment. 


\subsection{Wprowadzenie - obecność rzeczy jako preludium procesu (re)konstruowania przeszlości}

Tytułowe przeszłości fragmentaryczne, a właściwie - zdefragmentowane - to inaczej konglomerat minionych i obecnych „teraźniejszości”, połączonych w ujmowanej w szerszym metodologicznym kontekście współczesności (zob. Zalewska 2017: 51). To kulturowe palimpsesty, które z biegiem czasu, pod wpływem działalności antropogenicznej, konstytuują się w przestrzeni geograficznej. Podczas gdy jedne elementy są usuwane (często pozostawiając swoiste krajobrazowe ślady), tożsamość krajobrazu budowana jest nieustannie przez kolejne, konstruowane i pojawiające się na skutek różnych procesów składowe (więcej o krajobrazie jako palimpseście m.in.: Bailey 2007; Kijowska, Kijowski, Rączkowski 2011: 105-107; Zalewska 2011). W realnym (materialnym) nurcie badawczym, tymi „kolejnymi” są reprezentanci spośród szerokiej kategorii określanej mianem ,rzeczy”. Rzeczy, to także z pozoru niemi aktorzy determinujący narrację archeologiczną. Osadzone zarówno w przemijającej teraźniejszości, jak i przeszłości pozostają łącznikami z czasem minionym, którego możemy w ten sposób doświadczać. Rzeczy bowiem zawsze stanowią potencjalne nośniki pamięci (zob. Golka 2009: 67-68). Czasowe kontinuum skutkuje również tym, że tak naprawdę każdy artefakt pozostaje równocześnie przedmiotem współczesnym, co implikuje jego rolę w dyskursie (zob. Kobiałka, Kajda 2017: 34). Historyczny, kulturowy i społeczny „ciężar” rzeczy - ich znaczenie w całej konstrukcji otaczającej nas rzeczywistości poświadcza m.in. wzrastające zainteresowanie nieantropocentrycznymi nurtami w badaniach humanistycznych, w tym prowadzonych z zakresu archeologii. Uznanie zdobył tzw. powrót do rzeczy/zwrot ku rzeczom - ku materialności (zob. m.in. Domańska 2006: 105; Olsen 2010; Hodder 2012). Uwaga kierowana jest m.in. na biografie przedmiotów (zob. m.in. Kobiałka 2018) i funkcjonowanie rzeczy w kontekście ich sprawczości (agency - zob. Domańska 2008: 34-36). To przez pryzmat i za sprawą szeroko ujmowanej kategorii rzeczy - nie tylko przedmiotów - artefaktów, ale także obiektów i warstw kulturowych - a zatem wielu kumulujących się lub rozproszonych świadectw działalności antropogenicznej na danym obszarze, uzupełniane są karty historii.

W jaki sposób wiedza na temat percypowanej za pośrednictwem rzeczy przeszłości, jak również (co nie mniej istotne) wiedza na temat ścieżek, które prowadzą do poznania tego co minione przedostaje się poza środowisko naukowe i funkcjonuje w szerszym, społecznym, pozaakademickim dyskursie? Problematyka funkcjonowania archeologicznych kreacji przeszłości w przestrzeni społecznej (w tym społecznego znaczenia archeologii) jest przedmiotem ożywionej dyskusji naukowej (zob. m.in. Kajda, Pawleta, Marciniak 2017). W studiach polskich na szczególne uznanie zasługują prace M. Pawlety (2012, 2015, 2016). Warto zwrócić uwagę również na prace dotyczące krajobrazu dziedzictwa (heritagescape), 
poddawanego refleksji naukowej m.in. przez archeolog M.-C.E. Garden (2004, 2006), która prowadzi badania na temat form i sposobów konstruowania tzw. przestrzeni dziedzictwa. $Z$ kolei np. w anglosaskich studiach geograficznych, analizy dotyczące zinstytucjonalizowanych, wtórnie aranżowanych czy naturalnych zasobów dziedzictwa kulturowego dokonywane są w ramach geografii dziedzictwa (geography of heritage) (zob. Graham, Ashworth, Tunbridge 2000).

Pomimo prowadzonych w tym zakresie studiów, wydaje się jednak, że pobocznymi pozostają analizy przestrzenne - $\mathrm{w}$ tym te holistycznie ujmujące problematykę współczesnych konceptualizacji materialnych składowych krajobrazu kulturowego. Jak historyczność materializowana jest w nam współczesnych krajobrazach kulturowych? Wydaje się, że w zakorzenionej kulturowo idei skansenu czy muzeum brakuje miejsca na podejmowanie wielu ważnych zagadnień związanych $\mathrm{z}$ wiedzą o przeszłości, w tym na zadawanie pytań o to, w jaki sposób przeszłość, której doświadczamy we współczesności jest w niej konstruowana. Co więcej, pomijając popkulturowe wizerunki naukowców, niewiele miejsca poświęca się „kreatorom” przeszłości - a więc archeologom i mechanizmom poznawania przez pryzmat rzeczy życia naszych przodków (zob. Kołodziejczyk 2014).

$\mathrm{W}$ opracowaniu poddano rozważaniu problematykę form popularyzowania archeologii w środowisku pozaakademickim, zarówno w kontekście dyscypliny naukowej, jak i jej dorobku. Głównym celem pracy jest krytyczne omówienie, na wybranych przykładach, dominujących narracji w popularyzacji archeologii, ze szczególnym uwzględnieniem ich aspektu krajobrazowego, za sprawą włączenia do analizy perspektywy geograficznej - geografii historycznej. Szczególną uwagę poświęca się w niej analizom dotyczącym krajobrazów kulturowych oraz dziedzictwu kulturowemu jako komponentowi przestrzeni geograficznej.

W zakresie przestrzennym praca dotyczy przykładów popularyzacji archeologii z terytorium Polski. Z uwagi na stosunkowo obszerną literaturę przedmiotu traktującą o poszczególnych formach popularyzacji archeologii, w tym dotyczącą silnie z nią związanej turystyki kulturowej, omówieniu w pracy podlegają formy popularyzacji archeologii $\mathrm{w}$ ujęciu zgeneralizowanym, sprowadzonym do poszczególnych, głównych ich rodzajów, w obrębie których omówieniu szczegółowemu poddano reprezentacje posiadające cechy charakterystyczne dla omawianych form popularyzacji.

\subsection{Zamknięte i otwarte przestrzenie kreowanej przeszlości jako „okna archeologii" - czyli klasyczne krajobrazy dziedzictwa}

Muzea i skanseny, bogate w działania o charakterze rekonstrukcyjnym festyny i festiwale archeologiczne oferują nam swego rodzaju wejrzenie w przeszłość, osobiste doświadczenie życia społeczności i kultur, które przeminęły, pozostawiając po sobie kulturę materialną. Na jej bazie możemy dociekać mniej lub 
bardziej szczegółowo na temat m.in. codziennego życia określonych wspólnot. Niewątpliwie taki rodzaj doświadczania historii - który pozwala na swego rodzaju przeniesienie się w czasie, pozostaje atrakcyjną formą promowania wiedzy o przeszłości i popularyzacji archeologii, szczególnie wśród najmłodszych odbiorców, którym trudno wyobrazić sobie np. funkcjonowanie pradziejowych czy historycznych osad na podstawie tego, co zobaczyliby na terenie stanowiska archeologicznego. Dlatego też formy rekonstrukcyjne cieszą się niesłabnącą popularnością i są chętnie wykorzystywane, przyciągając odbiorców, szczególnie w kontekście tworzenia produktów turystycznych - np. tereny zamkowe, na których prowadzone są turnieje rycerskie, pola pobitewne, na których odbywają się inscenizacje militarne, miejsca dawnych osad i te utożsamiane $\mathrm{z}$ dawnym sacrum - np. Piknik Jaćwieski w Starych Juchach (pow. ełcki - fot. 1) organizowany na terenie domniemanego grodziska i w sąsiedztwie tzw. kamienia (ołtarza) ofiarnego. Ogół takich przedsięwzięć określony został mianem „utowarowienia” (komercjalizacji) przeszłości (zob. Pawleta 2012: 366).
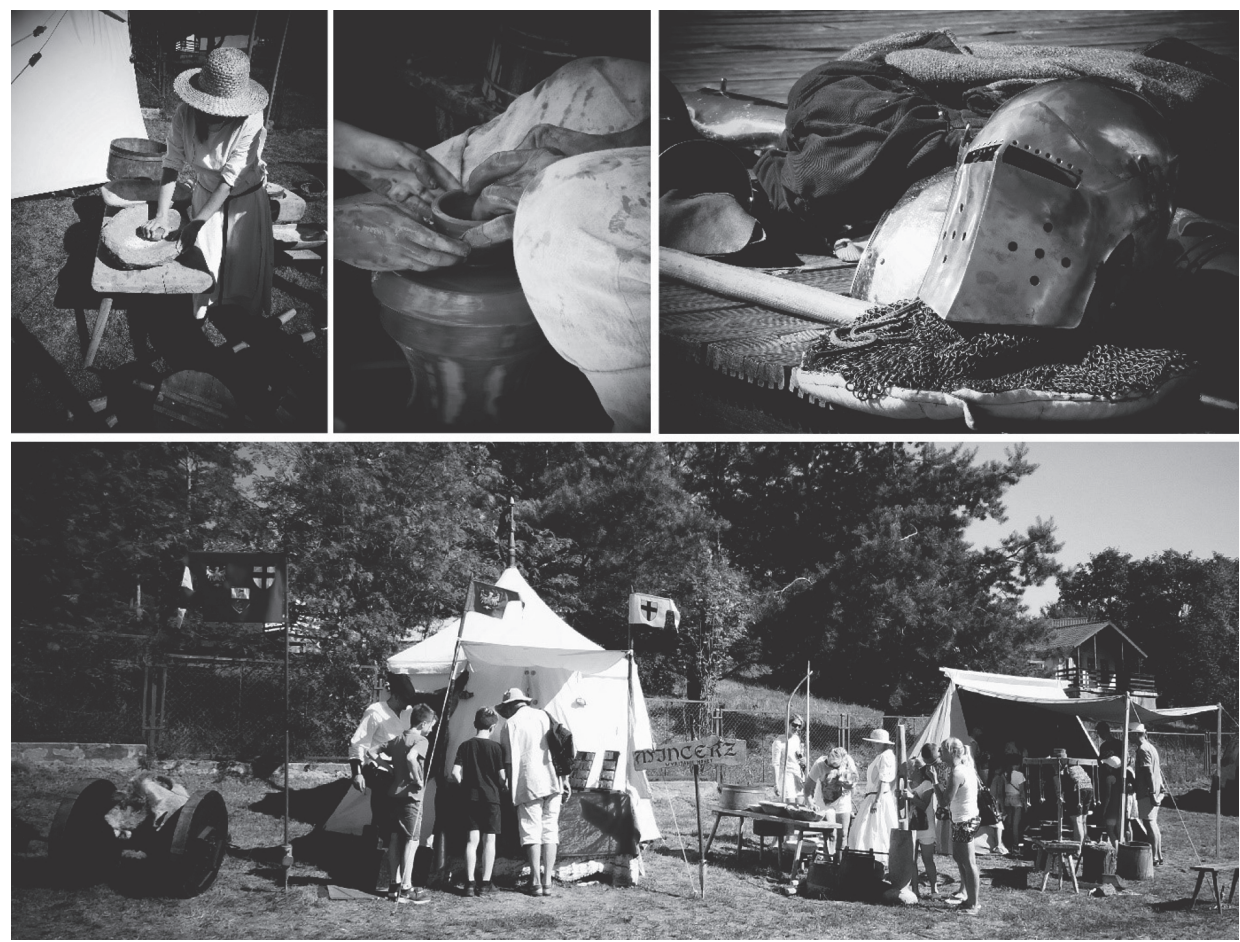

Fot. 1. Stare Juchy (pow. ełcki) - obserwacja fotograficzna podczas XII Pikniku Jaćwieskiego

fot. A. Majewska (2018) 
Wspomniane powyżej formy popularyzacji archeologii organizują tzw. przestrzeń - krajobraz dziedzictwa (heritagescape), któremu w dyskursie naukowym, szczególnie w badaniach anglosaskich i amerykańskich, poświęca się osobną uwagę, co skutkowało m.in. skonstruowaniem nowych ujęć teoretycznych w analizowaniu tego rodzaju krajobrazu (Garden 2004).

Przyjmując perspektywę geograficzną w badaniach nad materialną strukturą krajobrazu, autorka proponuje dualistyczny podział zachowanych reliktowo i/lub konstruowanych krajobrazów dziedzictwa na:

- krajobrazy stałe, jak: muzea, skanseny,

- krajobrazy efemeryczne, jak: inscenizacje historyczne, pikniki, festyny, festiwale.

Każdy z rodzajów krajobrazu dziedzictwa posiada odrębne walory w kwestii promowania dziedzictwa kulturowego i nauk, które przyczyniają się do jego „odkrywania”, zrozumienia i ochrony (np. historia, archeologia, etnografia). Najbardziej zamkniętą pod względem przestrzennym formą popularyzacji osiągnięć archeologii jest forma muzealna. W tradycyjnym ujęciu, zabytki funkcjonują w niej w zupełnym oderwaniu od szerszych kontekstów, stanowiąc eksponaty - swoisty „wyrywek” najciekawszych znalezisk i odkryć dokonanych w wyniku badań. Wydaje się, że ekspozycje takie, których tradycje sięgają wielu wieków wstecz, nie przystają do wymogów współczesności - niewiele mówią na temat specyfiki dyscypliny i ważności tak podkreślanego przez archeologów kontekstu. Patrząc przez pryzmat takich wystaw, obserwator odnosi niechybne wrażenie, że centrum zainteresowania archeologii jako nauki są rzeczy, ale w prostym, materialistycznym i wartościującym ujęciu. A przecież archeologa, jako badacza, interesuje całościowy obraz życia dawnych społeczności jakie postrzega przez pryzmat różnorodnych przedmiotów, warstw, obiektów i ich wzajemnych powiązań, czego wydaje się nie sposób przedstawić w tradycyjnej przestrzeni muzealnej. Potrzeby ukazywania tego są jednak dostrzegane, o czym świadczą nowoczesne założenia muzealne, w ramach których dochodzi do swego rodzaju przenikania się przestrzeni - stanowisk archeologicznych i narracji wystawienniczej, które choć sztucznie wykreowane, dają namiastkę sedna archeologicznych dociekań. Autorka ma tu na myśli placówki muzealne, w których struktury wkomponowane są prawdziwe stanowiska archeologiczne lub ich wierne rekonstrukcje, gdzie w formie ,stopklatki” zainscenizowano przestrzenie, które imitują stan ,zatrzymany" w danym momencie eksploracji archeologicznej, np. Rezerwat Archeologiczny Genius Loci w Poznaniu czy Muzeum Historyczne Miasta Krakowa - oddział Podziemia Rynku. Przestrzenie te, choć zamknięte, bo znajdujące się wewnątrz obiektów muzealnych, naśladują pewne fragmenty przestrzeni geograficznej - także otwartej i rzeczywistej, np. poprzez ukazanie przekrojów nawarstwień kulturowych i reliktowo zachowanych obiektów architektonicznych (fot. 2). 

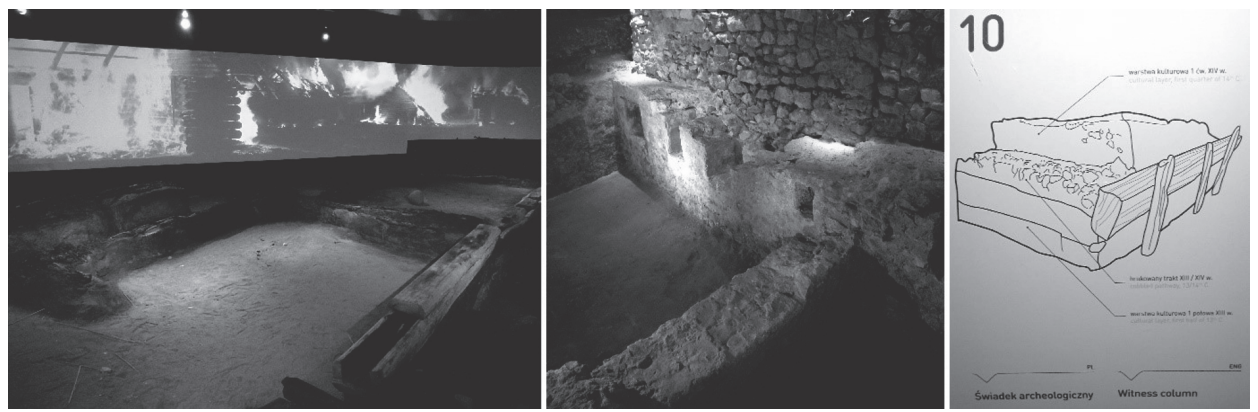

Fot. 2. Muzeum Historyczne Miasta Krakowa - oddział Podziemia Rynku Głównego w Krakowie. Reliktowa i zaaranżowana przestrzeń dziedzictwa fot. A. Majewska (2018)

Efemeryczny krajobraz dziedzictwa jest z kolei przejściową, tymczasową kreacją przeszłości w teraźniejszości. Ponadto krajobrazy efemeryczne zazwyczaj cechuje pewna nieregularność występowania, tylko niekiedy posiadają one cechy cykliczności (Mocior i in. 2014). Tego typu przestrzeń, w ramach krajobrazu kulturowego, konstytuują np. festiwale czy festyny archeologiczne, które posiadają już zupełnie odmienny charakter i wartości w kontekście popularyzacji wiedzy. Brakuje w nich zazwyczaj elementów stanowiących realne powiązania z przeszłością - czyli zabytków. Dominuje natomiast rekonstrukcja/inscenizacja - mniej lub bardziej wierna, a nacisk kładziony jest bezsprzecznie na aspekty społeczne, nie zaś na rzeczy, które współorganizują przestrzenie muzealne. Mamy tu do czynienia z tzw. teatralizacją przeszłości, która w pewien sposób obrazuje stosunek człowieka współczesnego do tego, co minione (por. Pawleta 2016: 251). Krajobraz efemeryczny umożliwia jednak tworzenie pomostów pomiędzy nie tymi najmniejszymi elementami archeologicznych dociekań, czyli ruchomym materiałem zabytkowym, ale pomiędzy całymi miejscami - stanowiskami archeologicznymi, które posiadając swój genius loci, ułatwiają kreowanie przeszłości we współczesności. Tak jest np. podczas organizowania już wspomnianych inscenizacji w miejscach wydarzeń historycznych (które przecież stają się na przestrzeni lat obiektami podlegającymi działalności stricte archeologicznej). Być może w przypadkach takich brakuje jedynie jeszcze tego jednego, trzeciego ogniwa, którym oprócz ogólnej wiedzy o stanowisku archeologicznym i nawiązującej do niego inscenizacji historycznej, jest omówienie wyników przeprowadzonych wcześniej w tym miejscu badań archeologicznych. 


\subsection{Popularyzacja archeologii in situ - sposób na rehabilitację dyscypliny}

Szczególnym rodzajem efemerycznego krajobrazu dziedzictwa są stanowiska archeologiczne, w czasie prowadzonych na ich terenie archeologicznych badań inwazyjnych (wykopaliskowych, np. sondażowych, szerokopłaszczyznowych). Obserwacja prac archeologicznych na stanowisku połączona z możliwością uzyskania rzetelnej wiedzy na temat prowadzonych badań jest według autorki jednym z najbardziej wartościowych sposobów popularyzacji archeologii - zarówno jako dyscypliny naukowej, jak i całości tego, co obejmuje, a więc materialnego dziedzictwa kulturowego. Bezpośredni kontakt z tym, jak prace są prowadzone, może szczególnie u młodego odbiorcy przyczynić się do uwrażliwienia na wartość, jaką posiada dziedzictwo kulturowe i do zrozumienia potrzeby jego ochrony. Podobną, a nawet większą wartość ma współuczestniczenie w badaniach archeologicznych. Uspołecznienie archeologii - popularyzowanie jej w formach partycypacyjnych, angażujących osoby spoza środowiska zawodowego, to coraz częściej stosowane praktyki. Wykorzystywane są szczególnie w dużych projektach naukowych, w których oprócz realizacji badań podstawowych, możliwym jest również przeznaczenie części środków na popularyzację wyników badań i działania prospołeczne, w tym np. związane z promowaniem historii lokalnej ${ }^{1}$.

Przykładem popularyzacji archeologii poprzez działania partycypacyjne o charakterze wspólnotowym, społecznym są zadania, które realizowane były w ramach zespołowego projektu badawczego pt. „Miejsca pamięci i zapomnienia. Badania interdyscyplinarne północnych terenów Jury Krakowsko-Częstochowskiej”, kierowanego przez $\mathrm{O}$. Ławrynowicza $\mathrm{z}$ łódzkiego ośrodka archeologicznego (zob. więcej: Wejland, Ławrynowicz, red. 2016; http://najurze.uni.lodz.pl/). W ramach tego projektu możliwość uczestniczenia w badaniach - poznania ich specyfiki i zapoznania się z podstawowymi zasadami warsztatu archeologicznego mieli m.in. studenci etnografii, którzy prowadzili równolegle także badania w zakresie swojej dyscypliny. Możliwość uczestniczenia w archeologicznym module badawczym przyczyniła się do umocnienia współpracy interdyscyplinarnej nie tylko w ramach owego projektu, ale i do budowania pomostu pomiędzy obiema dyscyplinami (zob. Badji, Majewska, w druku). Ponadto terenowe zadania projektowe realizowane $\mathrm{w}$ sezonie letnim podsumowywała wystawa, która

\footnotetext{
${ }^{1}$ Warto wymienić tu chociażby projekt pt. „Muszyna-Plaveč: Odkrywamy zapomnianą historię i kulturę polsko-słowackiego pogranicza”, kierownik badań archeologicznych: mgr inż. Artur Ginter; projekt realizowany ze środków Europejskiego Funduszu Rozwoju Regionalnego, Interreg V-A Polska-Słowacja 2014-2020, Oś 1 - ochrona i rozwój dziedzictwa przyrodniczego i kulturowego obszaru pogranicza. W ramach projektu wydawana jest m.in. okolicznościowa gazeta lokalna, w której na bieżąco przybliżane są wyniki z prowadzonych badań archeologicznych i etnograficznych, http://muszyna.pl/pl/965/ 2540/wiesci-muszynskie-wyd-2.html (dostęp: 4.08.2018).
} 
była każdorazowo organizowana w centrach gmin wiejskich, na terenie których prowadzono badania archeologiczne i etnograficzne. Wstępne wyniki badań, opracowane na bieżąco jeszcze podczas pobytu terenowego, prezentowane były w formie popularnonaukowych plansz wykonanych przez studentów uczestniczących w pracach badawczych. Wystawy będąc rodzajem popularyzacji wiedzy o dziedzictwie kulturowym miejscowości, stanowiły również formę podziękowania dla mieszkańców za życzliwość i udział w badaniach (szczególnie etnograficznych). Zdaniem autorki działania takie sprzyjają m.in. budowaniu dobrych relacji pomiędzy nauką a środowiskiem pozaakademickim.

Innym projektem, który można podać tu za przykład popularyzacji archeologii w miejscu prowadzenia badań jest kierowany przez A. Zalewską projekt: „Archeologiczne przywracanie pamięci o Wielkiej Wojnie. Materialne pozostałości życia i śmierci w okopach na froncie wschodnim oraz stan przemian krajobrazu pobitewnego w rejonie Rawki i Bzury (1914-2014)". Jak wskazuje kierownik projektu, jednym z jego celów jest „kształtowanie współczesnej wrażliwości i świadomości historycznej społeczności lokalnych", a możliwości takich upatruje właśnie w archeologii, która posiada ku temu znaczny potencjał. W ramach projektu zaplanowano i przeprowadzono szereg działań prospołecznych, jak spotkania z lokalną społecznością, prelekcje, wykłady, wystawy, lekcje terenowe z dziećmi i dorosłymi - lekcje historii w terenie (w tym omawianie wyników badań archeologicznych w miejscach ich prowadzenia) (więcej: Archeologiczne przywracanie pamięci o Wielkiej Wojnie..., archeomemory.pl).

Prospołeczne działania mają szczególne znaczenie w kontekście przeszłości naznaczonej konfliktem - kiedy rzecz dotyczy zrozumienia dziedzictwa związanego z wojną, zwiększenia wśród społeczności wiedzy na temat dziedzictwa, poszanowania miejsc pochówku czy, jak podaje A. Zalewska (2015) - kształtowania empatii dla doświadczonych wojną w przeszłości, a także, jak dodałaby autorka - także współcześnie. Oczywiście takie wartości można odnieść również względem dziedzictwa chronologicznie starszego. Popularyzacja archeologii dotyczącej czasów najnowszych, jak i dziedzictwa społeczności pradziejowych, generuje ogólne zwiększenie świadomości na temat składników krajobrazu kulturowego oraz potrzeby kompleksowej ochrony i dbałości o spuściznę pokoleń żyjących przed nami. Działania prospołeczne w archeologii A. Zalewska (2014) postuluje jako konieczny i integralny element praktyki archeologicznej, co nazywa procesem uspołeczniania archeologii. Ponadto wykłada, że niezwykle istotnymi składowymi „uspołecznionej” archeologii są:

- wspólnotowe badania wykopaliskowe,

- opieka społeczności lokalnych nad stanowiskami archeologicznymi po zakończeniu badań, 
- czynienie ze stanowiska archeologicznego istotnego społecznie elementu lokalnej tożsamości,

- okołoarcheologiczne działania edukacyjne i rozrywkowe (Zalewska 2014: 23). Trzecim przykładem archeologii angażującej społecznie są działania prowadzone przez archeologa R. Hermana, m.in. na terenie zamku w Ełku. Organizowane przez niego „Wakacje z historią” cieszą się niesłabnącą popularnością i stanowią według autorki kwintesencję popularyzacji archeologii (fot. 3). Uczestniczenie pod okiem specjalistów w badaniach archeologicznych umożliwia bezpośredni kontakt nie tylko z materią zabytkową, ale również zapoznanie się z warsztatem archeologicznym. Ponadto uwrażliwia na potrzebę ochrony dziedzictwa i sprzyja zmianom w jego percepcji - zauważaniu „historyczności” obiektów i przestrzeni w otaczającym nas świecie, kształtowaniu dobrych praktyk, dostrzeganiu konieczności dbałości o krajobraz kulturowy i poszanowania środowiska naturalnego i antropogenicznego. To właśnie tzw. turystyka żywa bądź ożywiona historia (living history tourism) (zob. więcej Pawleta 2012: 368), może stanowić siłę napędową popularyzacji archeologii $\mathrm{w}$ jej najlepszym wydaniu. Umożliwia dotarcie do środowisk pozaakademickich z prawdziwym, żywym przekazem i pokazanie pracy archeologa i całego procesu poznawania przeszłości, co pominięte zostaje w przypadku statycznych form prezentacji dorobku archeologii (np. muzea, skanseny, wystawy).

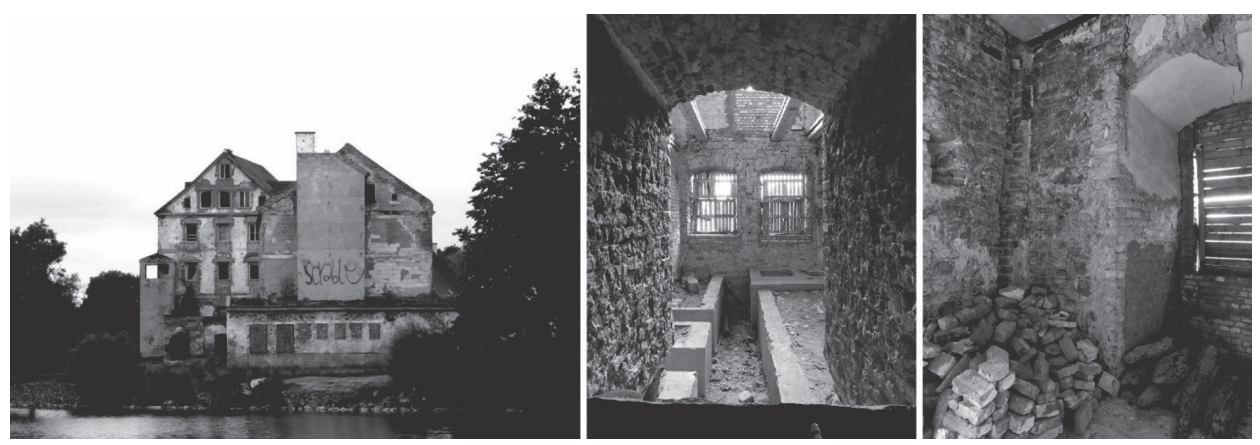

Fot. 3. Zamek w Ełku - obserwacja fotograficzna podczas archeologicznego oprowadzania po obiekcie

fot. A. Majewska (2016)

\subsection{Podsumowanie}

Pomimo tego, że w pracy nie dokonano statystycznych porównań dotyczących poszczególnych form popularyzacji archeologii w Polsce, poddając refleksji ich wybrane reprezentacje, według spostrzeżeń autorki zauważalna jest znacząca dysproporcja pomiędzy statycznymi, muzealnymi formami popularyzacji archeologii 
(jako nauki oraz jej dorobku), w postaci dominujących w tym zestawieniu ekspozycji muzealnych a formami popularyzacji interaktywnej i partycypacyjnej, wśród których zauważalne są przede wszystkim właściwie okołoarcheologiczne festiwale. Nie należy jednak poczytywać tej dysproporcji na niekorzyść, ponieważ zarówno instytucje muzeów, jak i pozostałe omówione formy stanowią materialne nośniki lub tzw. implanty pamięci (zob. Golka 2009), niezbędne do jej zachowywania i podtrzymywania, a przez to stanowiące integralne składowe współczesnej kultury.

Wybrane działania popularyzujące archeologię omówione przez autorkę w opracowaniu, w szczególności dotyczące obcowania $\mathrm{z}$ archeologią in situ - w miejscach stanowisk archeologicznych, stanowią przykłady tzw. turystyki archeologicznej, właściwie wykraczając poza kanon turysty-obserwatora za sprawą swojej formy wyraźnie partycypacyjnej. Tego rodzaju turystyka kulturowa ukierunkowana jest na czynności, takie jak: zwiedzanie wykopalisk i spotkania $\mathrm{z}$ archeologami, odwiedzanie stanowisk archeologicznych - wszystkie działania ukierunkowane są na kulturę - obcowanie z nią przede wszystkim w jej oryginalnym kontekście przestrzennym (zob. więcej: Werczyński 2011: 10-11). Turystyka archeologiczna, choć wydaje się atrakcyjnym pod wieloma względami alternatywnym odgałęzieniem tradycyjnego nurtu turystyki, nie stanowi kierunku dominującego. Składać się może na to co najmniej kilka czynników, które autorzy poruszający tę problematykę nadmieniają w swoich analizach. Do ograniczników rozwoju samej turystyki archeologicznej, a więc i możliwości popularyzacji archeologii, szczególnie terenowej, wciąż należą:

- stosunkowo słabe oznakowanie obiektów archeologicznych - wartych odwiedzenia stanowisk - za pomocą tablic informacyjnych oraz na mapach turystycznych,

- brak infrastruktury lub brak przystosowania istniejącej infrastruktury towarzyszącej obiektom archeologicznym na potrzeby turystyczne, np. szlaki piesze, konne, rowerowe itd., brak możliwości dojścia do obiektów lub zaparkowania w pobliżu,

- istniejący konflikt interesów pomiędzy koniecznością ochrony dziedzictwa archeologicznego a sposobami i formami jego popularyzacji, często ingerującymi w tkankę zabytkową,

- nieprzystosowanie atrakcyjnych z punktu widzenia obiektów do potrzeb turystycznych oraz nieuregulowany status prawny obiektów uniemożliwiający podjęcie określonych działań mających np. na celu zabezpieczenie obiektów np. w formie trwałej ruiny, która to forma również stanowi ważny element historycznego krajobrazu kulturowego (zob. więcej: Chlebowska 2004),

- niedostępność wielu obiektów - tereny prywatne lub chronione (np. zwiedzanie za zgodą dyrekcji parków narodowych), w tym szlaki turystyczne omijające obiekty (por. Faracik 2000: 146-147), 
- funkcjonowanie jako miejsc destynacji turystyki archeologicznej stanowisk, które znane są od wielu lat i wykreowany został wokół nich stały ruch turystyczny, przy pomijaniu wielu nowych, które mogłyby znaleźć odzwierciedlenie w ofertach turystycznych, które nie są aktualizowane, zmieniane, bazując wyłącznie na tradycyjnych destynacjach (por. Kaczmarek 2010); odpowiedzią na zapotrzebowanie odwiedzania „,nowych” miejsc, szczególnie pod względem turystyki indywidualnej, są w związku z tym różnego rodzaje festiwale i festyny archeologiczne,

- brak informacji na temat wydarzeń i niedostateczne promowanie archeologii w środkach masowego przekazu, np. w Internecie - na kontach społecznościowych, za pośrednictwem blogów i stron internetowych, co znacznie przyczyniłoby się do ocieplania wizerunku instytucji, dyscypliny i „uspołecznienia” jej działań (zob. Zdziebłowski red. 2014).

Zaproponowany przez autorkę podział na stałe i efemeryczne krajobrazy dziedzictwa, przedstawiony w kontekście form popularyzacji archeologii i jej dorobku, stanowił punkt wyjścia do wskazania szczególnych walorów tych efemerycznych krajobrazów dziedzictwa, których wiążącymi składowymi są oryginalne obiekty archeologiczne. Współczesne aranżacje przestrzeni muzealnych, w których eksponuje się oryginalną bądź rekonstruowaną materię archeologiczną w postaci obiektów i przekrojów warstw kulturowych, pokazują potrzebę i atrakcyjność tego typu prezentacji dorobku archeologii w środowisku społecznym. Ponadto, obiekty tego typu stanowią wyjątkowe przykłady integracji przestrzeni geograficznej z przestrzeniami izolowanymi/zamkniętymi (które już do geograficznych nie należą). Pojawiają się zatem nowe problemy badawcze dotyczące sposobów funkcjonowania owych konstruowanych przestrzeni dziedzictwa, które mogą być rozpatrywane na pograniczach dyscyplin, nie tylko geografii i archeologii, ale również historii, muzealnictwa czy etnografii.

\section{Literatura}

Badji J., Majewska A., (b.d.), Archeologia wspótczesności i etnografia. Wspótpraca, doświadczenia, korzyści - przyktad badań na Jurze Krakowsko-Częstochowskiej, Wydawnictwo Uniwersytetu Adama Mickiewicza w Poznaniu (w druku).

Bailey G., 2007, Time perspectives, palimpsests and the archaeology of time, „Journal of Anthropological Archaeology", 26: 198-223.

Chlebowska D., 2004, Trwała ruina w Polsce koniecznym świadkiem historycznego krajobrazu, „Wiadomości Konserwatorskie”, 16: 76-83.

Domańska E., 2006, Historie niekonwencjonalne, Wydawnictwo Poznańskie, Poznań.

Domańska E., 2008, Problem rzeczy we wspótczesnej archeologii, [w:] Kowalewski J., Piasek W., Śliwa M. (red.), Rzeczy i ludzie. Humanistyka wobec materialności, Instytut Filozofii Uniwersytetu Warmińsko-Mazurskiego w Olsztynie, Olsztyn: 27-60. 
Faracik R., 2000, Zabytki archeologiczne jako obiekty zainteresowania turystycznego na przykładzie Krakowa i okolic, „Prace Geograficzne”, 106: 141-149.

Garden M.-C.E., 2004, The Heritagescape: Exploring the Phenomenon of the Heritage Site, University of Cambridge ( $\mathrm{PhD}$ thesis).

Garden M.-C.E., 2006, The Heritagescape: Looking at Landscapes of the Past, „International Journal of Heritage Studies", 12(5): 394-411.

Golka M., 2009, Pamięć społeczna i jej implanty, Warszawa.

Graham B., Ashworth G.J., Tunbridge J.E., 2000, A Geography of Heritage, Oxford University Press, New York.

Hodder I., 2012, Entangled. An Archaeology of the Relationships between Humans and Things, Wiley-Blackwell.

Kaczmarek K., 2010, Turystyka archeologiczna, „Turystyka Kulturowa”, 1: 4-13.

Kajda K., Pawleta M., Marciniak A., 2017, Archeologia, dziedzictwo archeologiczne i ich społeczne znaczenie w oczach wspótczesnych Polaków, „Folia Praehistorica Posnaniensia", 22: 71-84.

Kijowska J., Kijowski A., Rączkowski W., 2011, Krajobraz i polityka - wybrane aspekty wpływu decyzji politycznych na zmiany krajobrazu w Polsce, „Prace Komisji Krajobrazu Kulturowego. Niematerialne wartości krajobrazów kulturowych”, 15, Komisja Krajobrazu Kulturowego PTG, Sosnowiec: 103-115.

Kobiałka D., 2018, 100 years later: the dark heritage of the Great War at a prisioner-of-war camp in Czersk, Poland, „Antiquity”, 92(363): 772-787.

Kobiałka D., Kajda K., 2017, Archeologie współczesności jako odpowiedź na kryzys dyscypliny, „Ochrona Zabytków”, 2(271): 27-45.

Kołodziejczyk P., 2014, Archeolog w labiryncie popkultury, „Perspektywy Kultury”, 10: 7-24.

Mocior E., Franczak P., Hibner J., Krąż P., Nowak A., Rechciński M., Tokarczyk N., 2014, Typologia naturalnych krajobrazów efemerycznych w świetle dotychczasowych badań, [w:] Krąż P. (red.), Współczesne problemy i kierunki badawcze geografii. T. 2, Kraków: 77-101.

Olsen B., 2010, In Defense of Things: Archaeology and the Ontology of Objects (Archaeology in Society), Rowman Altamira, Stanford.

Pawleta M., 2012, Rekonstrukcje i inscenizacje przeszłości $w$ perspektywie turystyki archeologicznej w Polsce, [w:] Garncarski J. (red.), Skanseny archeologiczne i archeologia eksperymentalna szansą na rozwój turystyki, Muzeum Podkarpackie w Krośnie, Krosno: 364-387.

Pawleta M., 2015, Wybrane aspekty społecznego funkcjonowania wytworów wiedzy archeologicznej $i$ archeologii we współczesnej Polsce, ,Folia Praehistorica Posnaniensia", 20: 373-396.

Pawleta M., 2016, Przeszłość we współczesności. Studium metodologiczne archeologicznie kreowanej przeszłości w przestrzeni społecznej, Wydawnictwo Naukowe Uniwersytetu Adama Mickiewicza w Poznaniu, Poznań.

Wejland A.P., Ławrynowicz O. (red.), 2016, Miejsca pamięci i miejsca zapomnienia. Interdyscyplinarne badania na Jurze Krakowsko-Częstochowskiej. Raport z badań, T. 1: Wprowadzenie metodologiczne, Instytut Archeologii, Uniwersytet Łódzki, Łódź. 
Werczyński D., 2011, Archeoturystyka na Dolnym Śląku. Stan zagospodarowania obiektów i perspektywy rozwoju, [w:] Widawski K. (red.), Turystyka kulturowa na Dolnym Ślasku - wybrane aspekty, T. 2, Instytut Geografii i Rozwoju Regionalnego, Uniwersytet Wrocławski, Wrocław: 9-32.

Zalewska A., 2011, Archeologiczny „,palimpsest” jako specyficzna postać interakcji teraźniejszości z..., [w:] Marciniak A., Minta-Tworzowska D., Pawleta M. (red.), Wspótczesne oblicza przeszłości, Wydawnictwo Poznańskie, Poznań: 115-130.

Zalewska A., 2014, Prospołeczna, partycypacyjna i „wspólnotowa” archeologia bliskiej przeszłości jako sposób na nadawanie sensu trwaniu (ludzi i rzeczy) oraz jako antidotum na niedostatki wiedzy i trywializację przeszłości, „Studia Humanistyczne AGH”, 13(2): 19-39.

Zalewska A., 2015, Między złem a dobrem kultury. Niematerialne wartości materialnych pozostałości po XX-wiecznych konfliktach, [w:] Kobyliński Z., Wysocki J. (red.), Konserwacja zapobiegawcza środowiska. Dziedzictwo niematerialne i pamięć, Wydawnictwo Fundacji Archeologicznej, Warszawa: 157-164.

Zalewska A.I., 2017, Archeologia czasów wspótczesnych i (nie)moc działania materialnych śladów Wielkiej Wojny w Polsce, „Ochrona Zabytków”, 2(271): 47-77.

Zdziebłowski Sz. (red.), 2014, Cyfrowy Archeolog - podręcznik promocji archeologii w nowych mediach, Muzeum Archeologiczne w Poznaniu, Poznań.

\section{Źródła internetowe}

Archeologiczne przywracanie pamięci o Wielkiej Wojnie. Materialne pozostatości życia i śmierci w okopach na froncie wschodnim oraz stan przemian krajobrazu pobitewnego w rejonie Rawki i Bzury (1914-2014), www.archeomemory.pl (dostęp: 15.06.2018).

Miasto i gmina uzdrowiskowa Muszyna: Muszyna.pl, http://muszyna.pl/pl/965/2540/wiesci-muszynskie-wyd-2.html (dostęp: 4.08.2018).

Na Jurze, http://najurze.uni.lodz.pl/ (dostęp: 3.11.2018).

Historia artykutu

Data wpływu: 27 lipca 2018

Data akceptacji: 5 listopada 2018 